\title{
As três fases do maxixe música
}

\section{HENRIQUE LEAL CAZES*}

\begin{abstract}
RESUMO: "As três fases do maxixe música" é uma proposta de periodização e organização das informações relativas exclusivamente aos aspectos estilístico-musicais do maxixe. Embora tenha sido tema de muitos trabalhos dentro e fora do ambiente acadêmico, os trabalhos abordaram quase sempre aspectos da dança sensual e do choque que esta causou aos padrões moralistas do século XIX e início do XX. As três fases propostas correspondem respectivamente a: experiências de sincopação da polca, o maxixe funcional e o maxixe levada, que constituem três situações distintas. Na primeira, um repertório variado de experimentações, na segunda uma fórmula cristalizada pelo sucesso em espetáculos teatrais de variedades e na terceira, um sotaque, um acento que marcou a obra de Pixinguinha e de sua geração. Foram levados em conta os objetivos dos compositores em diferentes fases e uma atenção especial foi dada aos padrões rítmicos dos acompanhamentos, com dados extraídos de gravações realizadas nas três primeiras décadas do século XX.
\end{abstract}

PALAVRAS-CHAVE: maxixe; polca; choro; Pixinguinha.

\section{The Three Phases of the Genre Maxixe}

\begin{abstract}
The three phases of the genre maxixe" is a proposal of periodization and organization of the information relating exclusively to the musical aspects of the maxixe. Although it has been the subject of much research, both inside and outside the academic environment, the works usually dealt with aspects of the sensual dance and the shock that this caused to the moralistic standards of the nineteenth and early twentieth centuries. The three proposed phases correspond respectively to polka syncopation experiments, the functional maxixe, and the "maxixe groove", which constitute three distinct circumstances. In the first, a varied repertoire of experiments, in the second a formula crystallized in theatrical variety shows and in the third, an accent that marked the work of Pixinguinha and his generation. The goals of the composers were considered in different phases and special attention was given to the rhythmic patterns of the accompaniments, with data extracted from recordings made in the first three decades of the twentieth century.
\end{abstract}

KEYWORDS: Maxixe; Polka; Choro music; Pixinguinha. 


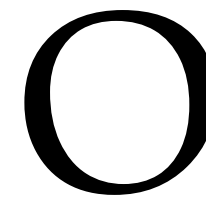

presente trabalho tem a intenção de reunir dados sobre o aspecto musical do maxixe, quase sempre pouco valorizado, em relação ao vocábulo, a dança e aos impactos por ela causados nos padrões moralistas do século XIX. A tentativa aqui é cruzar informações publicadas por músicos e pesquisadores, com partituras e observações sobre as gravações, não apenas as que tiveram o gênero musical "maxixe" no rótulo do disco ou anunciado antes da execução, mas também aquelas que, mesmo rotuladas e/ou anunciadas como polca ou tango e mesmo samba, na verdade estavam sendo tocadas como maxixe. Todas as gravações citadas no artigo fazem parte do acervo do Instituto Moreira Salles e são facilmente acessáveis.

Se buscarmos em textos do século XX informações sobre o maxixe, tanto de autores de perfil acadêmico, quanto de perfil jornalístico, encontraremos várias indicações de que se tratava apenas de uma dança. Luiz Heitor afirmou: "Maxixe foi, a princípio, uma maneira de dançar a polca, a habanera e o tango que desta tinha derivado" (AZEVEDO, 1956, p. 126). Ary Vasconcelos foi taxativo: "O maxixe era uma dança plebeia, considerada mesmo imoral, atentatória aos bons costumes" (VASCONCELOS, 1977, p. 16). O musicólogo Mozart Araújo concordava com a ideia de que maxixe era dança e escreveu em artigo no Jornal do Commercio de 5 de dezembro de 1965 que "maxixe é palavra de conteúdo mais coreográfico do que musical". Baptista Siqueira escreveu uma colaboração para o livro Maxixe: a dança excomungada do cronista Jota Efegê e foi na mesma linha: "não existe forma musical do maxixe" (EFEGÊ, 1974, p. 48). Mário de Andrade parecia entender de modo diferente pois no artigo "A originalidade do maxixe" publicado na revista Ilustração Musical de 1930 e citado por AZEVEDO (1956, p. 126) escreveu: "maxixe é uma resultante de processos afro-americanos de musicar". A proposta aqui é investigar esses processos que envolvem os aspectos musicais do maxixe e caracterizá-los em momentos distintos e finalidades específicas.

Uma atenção especial será dada ao acompanhamento, sua caracterização rítmica e sua relação com a melodia que está sendo acompanhada. Para essa caracterização, a construção rítmico-harmônica realizada pelos instrumentos de acompanhamento será usado o termo levada, bastante usual no campo da música 
popular. Para analisar as levadas, considerei mais relevante o conteúdo de gravações do que a rítmica anotada em partituras, pelo fato dessas edições muitas vezes simplificarem o acompanhamento e também porque é sabido que quase sempre nos grupos de choro o solista lia música, mas os acompanhadores de violão e cavaquinho tocavam de ouvido. Como as gravações do maxixe das fases 2 e 3 são em boa parte acompanhadas por esses músicos dos grupos de choro, penso que me aproximarei mais da realidade a partir dos dados obtidos nas gravações do que nas partituras editadas. Na investigação dessas gravações, valeu-me o ouvido treinado ao longo de muitos anos e o fato de tocar cavaquinho e violão, podendo perceber detalhes técnicos menos óbvios das execuções.

As três fases a que se refere o título e que serão detalhadas ao longo do artigo, são aqui propostas a partir da longa reflexão que tenho empreendido sobre o tema, desde que realizei uma varredura nas gravações da chamada fase mecânica (1902-1927), durante a pesquisa para o livro Choro do Quintal ao Municipal, entre 1996 e 1998. Penso que se organizarmos os dados em torno dessas três fases, ficará mais fácil entender a impressão tão dúbia que o maxixe causava, por exemplo, em Mário de Andrade, que no Ensaio sobre a música brasileira afirmou: "Os maxixes impressos de Sinhô são no geral banalidades melódicas. Executados, são peças soberbas" (ANDRADE, 1972, p. 23). Dois adjetivos tão díspares, parecem indicar, fora qualquer avaliação de performance, que estava Mário diante de uma matéria musical heterogênea, multifacetada. Diferentes faces, diferentes fases.

\section{Fase 1 - As experiências de sincopação da polca, o pré-maxixe}

A primeira fase estilística do maxixe está relacionada com a polca, vinda da região da Boêmia, atual República Checa, que chegou a Paris e dai se espalhou nos quatro cantos do mundo, influenciando decisivamente o surgimento de vários gêneros populares urbanos na segunda metade do século XIX11. A apropriação e

\footnotetext{
${ }^{1}$ Segundo o verbete do Dicionário de Música a polca é: “Dança da Boêmia que data dos princípios do século XIX, em compasso binário e ritmos vigorosos [...] No Brasil, a polca apareceu por volta de 1845. Fez enorme sucesso, passando dos salões para as ruas, e foi uma das matrizes em que se apoiaram os conjuntos de choro". (HORTA, 1985, p. 295).
} 
adaptação da polca nas Américas e Caribe, se deu através da inclusão de síncopes, antecipações de tempo e outras formas de contrametricidade, sempre com o objetivo de conectar a música ao corpo, de provocar o gesto e privilegiar a dança².

Dependendo de fatores como o sotaque musical do colonizador europeu, da origem do contingente de africanos escravizados trazidos para esse ou aquele país, de uma maior ou menor permissividade de convívio entre esses diferentes estratos sociais, o processo de sincopação da polca levou a resultados bem distintos. Proponho aqui a seguinte diferenciação entre modelos de sincopação:

Sincopação adicionada - o desenho melódico da polca original não sofre alteração, mas passa a ter no acompanhamento uma variedade de elementos contramétricos. É o caso de alguns temas gravados na coleção Voodoo Drums From Haití ${ }^{3}$ e da cúmbia tradicional da Colômbia, ou cumbia antica ${ }^{4}$.

Sincopação acentuada - sobre um acompanhamento marcadamente cométrico a melodia contrasta com antecipações e síncopes. É o caso do ragtime de Nova Orleans, do calipso de Trinidad Tobago e do mentho da Jamaica, esse gênero precursor do ska e do reggae.

Sincopação livre - os elementos contramétricos aparecem na melodia ou no acompanhamento, ou nos dois simultaneamente. É o caso do danzón de Cuba, da beguine da Martinica e da polca abrasileirada, que desemboca no maxixe.

No Brasil, a polca chegou em 1845, foi dançada no teatro e imediatamente começou a ser apropriada e modificada. É lícito supor que a sincopação livre aconteceu onde havia maior intimidade entre os elementos que se misturavam no processo e, nesse ponto corrobora a descrição da Festa do Divino de 1851 no Campo da Aclamação, escrita por Mello Moraes Filho e apresentada de forma muito elucidativa na tese O Império do Divino: festas religiosas e cultura popular no Rio de Janeiro, 1830-1900 de Martha Abreu. Nas palavras de Mello Moraes, a barraca do

\footnotetext{
2 Sobre o termo "contrametricidade", Sandroni resumiu o conceito proposto pelo etnomusicólogo Mieczyslaw Kolinski da seguinte maneira: "A métrica seria a infraestrutura permanente sobre a qual a superestrutura do ritmo tece suas variações. [...] Ora, em todos esses casos, o caráter variado do ritmo pode confirmar ou contradizer o fundo métrico que é constante. Kolinski cunhou os termos 'cometricidade' e 'contrametricidade' para exprimir estas duas possibilidades"' (SANDRONI, 2001, p. 21).

${ }^{3}$ Disponível em: $<$ https: / / www.youtube.com/watch?v=qBDbRYuGaEA $>$. Acesso em: 17/07/2019.

${ }^{4}$ Disponível em: $<$ https://www.youtube.com/watch?v=JmfsmCgXm8o $>$. Acesso em: 17/07/2019.
} 
Teles, conhecida como "As Três Cidras do Amor" foi a de maior sucesso na festa “não só pela originalidade das representações, mas ainda pela distinção de seus frequentadores..., a plebe e a burguesia, o escravo e a família, o aristocrata e o homem de letras". E nas palavras de Martha Abreu:

O que foi considerado maxixe, manifestava-se nas atrações de Teles a partir da "descida" das polcas dos pianos para a popular música do choro, no estilo da música dos barbeiros, com o velho violão, o cavaquinho e a flauta. (ABREU, 1996, p. 69).

Que a polca foi adotada e modificada por esses músicos populares é sabido, mas quais elementos foram mantidos e quais modificados? Primeiramente a forma rondó, voltando sempre à primeira parte da música, permaneceu como nas polcas europeias. O esquema de modulações foi igualmente mantido. Esse esquema era majoritariamente assim: para peças em tom maior, a segunda parte no relativo menor e a terceira no tom da subdominante. Para peças em tom menor, a segunda parte no relativo maior e a terceira no homônimo. Até os dias de hoje, boa parte do repertório de choro mantém essa relação entre tonalidades.

A respeito do que mudou, podemos começar pelo andamento, que caiu para facilitar a inclusão e a inflexão dos elementos contramétricos. Essa queda nos andamentos foi observada por Luciano Gallet na introdução de seus Exercícios Brasileiros, da década de 1920.

Da polca europeia veio a polca brasileira; desta o tango e dele o maxixe. Houve relaxamento de andamentos e ritmos, da polca ao maxixe. Este tem movimentos largos e amplos; acentuações exageradas; desenhos melódicos ondulantes e ritmos quebrados... (GALLET, 1928, p. 4).

Em termos absolutos os andamentos passaram do alegretto das polcas importadas, 112-120 BPM, para algo em torno de 88-96 BPM. O resultado facilitou a sincopação e a comunicação da música com o corpo, proporcionando o terreno para os "requebros", "meneios" e tantas outras expressões que foram usadas para descrever a sensualidade com que a polca abrasileirada foi dançada.

Para reforçar essa comunicação com o corpo, muitas vezes a melodia era tocada na região grave e isso afastava o resultado do modelo europeu e aproximava da prática musical de origem africana, onde as linhas mais movimentadas e variadas 
estão nos instrumentos graves, cabendo aos agudos o papel de acompanhamento em forma de ostinatos. No artigo "Variações sobre o maxixe", publicado em 26 de setembro de 1954 no jornal O Tempo - São Paulo, o maestro César Guerra-Peixe chamou a atenção para esse aspecto:

Colocariam com relevância especial essa baixaria..., salientada pelos instrumentos de tessitura grave. E o costume de empregá-la era tão apreciado que em certas ocasiões a melodia principal ficava colocada no registro grave, cabendo aos instrumentos restantes, dos registros médio e agudo, uma significação secundária por alguns momentos, na estrutura do trecho musical. (GUERRA-PEIXE, 1954, grifo do autor). ${ }^{5}$

O desenho melódico muito regular das polcas europeias, quase sempre constituído de semicolcheias, ganhou variedade, com a inclusão de elementos contramétricos na melodia. $\mathrm{O}$ acompanhamento também se tornou menos regular e ganhou maior interesse.

Por fim, o caráter também sofreu uma alteração, passando de alegre e saltitante para um tanto melancólico e lírico, com um fraseado "chorado" que iria nomear seus praticantes, os chorões.

A partir da chegada da polca ao Brasil e de sua imediata aceitação e apropriação, iniciou-se um verdadeiro concurso de ideias envolvendo compositores talentosos e que possuíam as ferramentas do conhecimento musical para ousar em suas experiências sincopantes. Se observarmos Henrique Alves de Mesquita (18301906), Joaquim Callado (1848-1880), Chiquinha Gonzaga (1847-1935), Ernesto Nazareth (1863-1934) e Anacleto de Medeiros (1866-1907), para citar as maiores lideranças, todos eles se envolveram com as experiências de sincopação da polca.

Os resultados foram muito diversos e justamente por isso a música dos chorões se constituiu num universo rico, múltiplo e resistente ao tempo.

As designações de gênero derivadas da polca também foram igualmente múltiplas: polca-lundu, polca-fado, polca-chula, polca-tango etc. O decano dessas experiências, Henrique Alves de Mesquita, as nomeava de polca-cateretê e escreveu

\footnotetext{
${ }^{5}$ Nota do editor: O artigo de Guerra-Peixe costumava ficar disponível no sítio guerrapeixe.com, que parece ter sido descontinuado. Assim, consideramos pertinente inseri-lo como documento suplementar na publicação.
} 
composições em que explorou de forma radical as antecipações de melodia e acompanhamento como o caso de "Quebra, quebra minha gente" (Ex. 1).

\section{Quebra, quebra minha gente}

Polca-cateretê

Henrique Alves de Mesquita (entre 1889 e 1895)

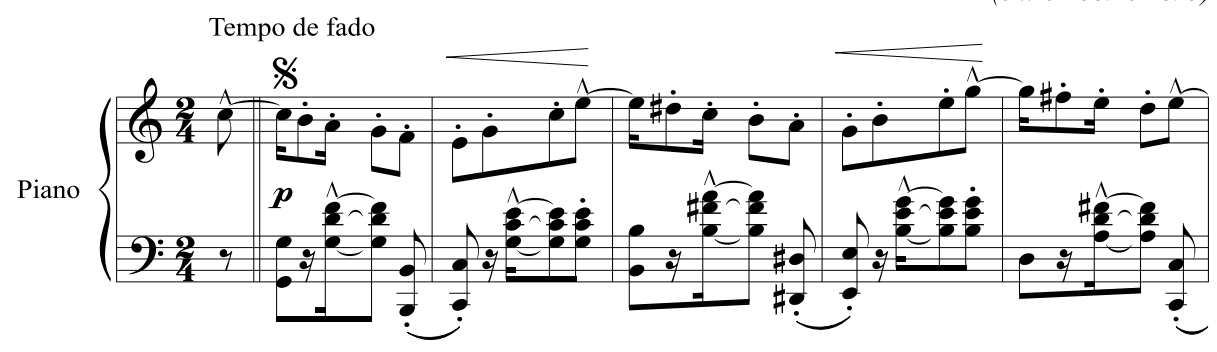

Ex.1 - compassos iniciais mostram intenção de surpreender com o ritmo. (www.henriquealvesdemesquita.com.br)

A descrição feita por Luiz Heitor da atuação de Ernesto Nazareth nessa fase do maxixe é clara e chama a atenção para o aspecto da circulação das experiências sincopantes:

O tango foi, como já vimos, o gênero que o consagrou; um tango especial, bem brasileiro, que disfarçava sob essa denominação mais polida a verdadeira natureza de maxixe plebeu e equívoco que o animava. Diversos processos rítmicos curiosos, autenticamente nacionais, mas que pela primeira vez recebiam a consagração da pauta, foram utilizados por esse compositor de músicas de dança, bem como sugestões provenientes do instrumental típico do choro, que ele habilmente reproduzia no piano. (AZEVEDO, 1956, p. 151).

Na mesma direção, Mário de Andrade escreveu, em texto datado de 1924 e publicado em Música, Doce Música:

Nazaré é um virtuose do ritmo. A síncopa em sua mão é o jogo de bolas na mão do pelotiqueiro. Faz dela o que quer. Ela se transfigura, move-se dentro do compasso, irrequieta e irregular, num saracoteio perpétuo. (ANDRADE, 1934, p. 141).

Os outros compositores citados também experimentaram bastante, explorando campos diferentes e obtendo resultados igualmente diversos, mas sempre buscando a surpresa rítmica que provoca o movimento, que comunica, que 
mexe com o corpo ou como escreveu Guerra-Peixe: “a característica gostosura do maxixe".

A partir de 1883, uma nova fase do maxixe iria se iniciar e se tornar temporariamente hegemônica, mas não terminar com a era das experiências, que vai se estender e aparecer transfigurada mais adiante na terceira fase do maxixe música. Mas por ora vamos para a segunda: o maxixe como música funcional, feita para o teatro de variedades.

\section{Fase 2 - O maxixe funcional}

Jota Efegê nos conta que em 10 de abril de 1883, coube ao ator Vasques (Francisco Corrêa), um dos que se apresentavam na barraca do caboclo Teles da Festa do Divino anos antes, o pioneirismo na apresentação de um maxixe no palco do Teatro Santana. Tratava-se do monólogo ou cena cômica "Ai Cara-Dura", que era a gíria da época para um bicão ou penetra em uma festa. Na cena o Sr. Manduca, o "cara-dura" é apresentado pelo dono da casa a Chiquinha, "a moça mais sacudida da roda" e ela diz-lhe ao ouvido: "quero ver isso de maxixe". Segue nos contando Efegê:

\footnotetext{
A indicação cênica diz que nesse momento a "orquestra", constituída por flauta, violão e cavaquinho, executa uma "polca-tango" e o Cara-Dura figurando os passos da dança canta ao ritmo da música:

No maxixe requebrado

Nada perde o maganão

Ou aperta a pobre moça

Ou arruma um beliscão!...

(EFEGÊ, 1974, p. 74).
}

A partir do sucesso dessa cena simplória e onde o ator apenas simulava os passos do maxixe, já que não tinha um par para dançar de fato, as companhias que produziam o teatro de variedades despertaram para esse filão, primeiramente anunciado como "m lundu requebrado", "uma polca crepitante", "um tango malemolente", para não usar o termo maxixe, que só alguns anos depois seria assumido.

Na intenção de alimentar o chamariz de público que o maxixe se tornou, decisivo para o sucesso das empreitadas teatrais, as companhias começaram a 
encomendar partituras e daí surgiram oportunidades de trabalho para compositores como Chiquinha Gonzaga.

Trazido pelos franceses do Alcazar Lírico para o Rio em 1859 (DINIZ, 2009, p. 134), o teatro musicado popular foi ganhando mais e mais público, interessado em se divertir com algo que não fosse nem muito longo como as óperas, nem muito sério como o teatro.

O teatro de revista põe o palco em contato com a rua. Nele se passava "em revista" os acontecimentos do ano, comentando-os humoristicamente. Os fatos são levemente alinhavados por um enredo de comédia. A música, elemento fundamental e grande ponto de sustentação desse tipo de espetáculo, é sempre alegre, graciosa e espirituosa. De uma exuberância decorativa, utiliza estribilhos jocosos e árias risonhas e jocosas. (DINIZ, 2009, p. 135).

Aos poucos foi surgindo um jeito brasileiro de fazer essas montagens. Começaram a aparecer os primeiros revistógrafos. Abriu-se um mercado de trabalho e Chiquinha Gonzaga, sempre sintonizada com as novidades e atenta às demandas do público, viu ali a sua chance. Investiu firme nas revistas e se tornou a maestrina da Praça Tiradentes.

A funcionalidade da música composta para as peças é muito bem definida por Edinha Diniz com o termo "exuberância decorativa". Para funcionar bem no teatro a música precisava ser simples, tanto a parte do repertório com letra, para ser aprendida e cantada por atores e atrizes, como a parcela instrumental do repertório, que seria coreografada. As letras por sua vez eram igualmente simples e diretas, provocativas de riso e insinuadoras de sensualidade. As melodias vocais e instrumentais precisavam ser de imediata compreensão e comunicação. Vez por outra, Chiquinha conseguia incluir num espetáculo algo um pouco mais elaborado como em 1895 na opereta burlesca de costumes nacionais Zizinha Maxixe, onde aparece no final do terceiro ato o "Cateretê-corta-jaca/Gaúcho", que mais tarde seria editado como "Gaucho-tango" e acabaria se tornando conhecido simplesmente como "Corta-jaca", mas, em média, o maxixe música da segunda fase era mais básico. E como curiosidade, fica a constatação de que quando cantado pela dupla Os Geraldos em gravação de 1905, o "Corta-jaca" teve sua melodia simplificada, evidenciando a necessidade dessa facilitação ao canto. 
Parte desse repertório foi gravada por atores e atrizes, ou cantores como Mario Pinheiro (1880-1923) e Bahiano (Manuel Pedro dos Santos, 1870-1944) na primeira década do século XX (SEVERIANO, 208, p. 61) e uma audição atenta de alguns exemplos como "A capital federal", de Nicolino Milano (1876-1962), da opereta homônima de Arthur Azevedo (1855-1908) ou "Baiana dos pastéis" de Chiquinha Gonzaga, aproxima mais o maxixe dessa fase do lundu, tal a ingenuidade da fórmula: uma introdução para dar o tom e exibir o requebro e depois quadrinhas de versos com melodia ainda mais básica. Enfim, um maxixe funcional, feito para agradar de primeira e fazer o espectador do teatro sair assobiando aquela lembrança.

Ao escutarmos essas gravações, podemos perceber que pelo menos até o início da década de 1920, a levada usual nos acompanhamentos dos sambas maxixados, ou sambas carnavalescos como eram anunciados, e maxixes assim intitulados, será muito próxima quando não idêntica àquela da maioria dos lundus gravados anteriormente (Ex. 2):

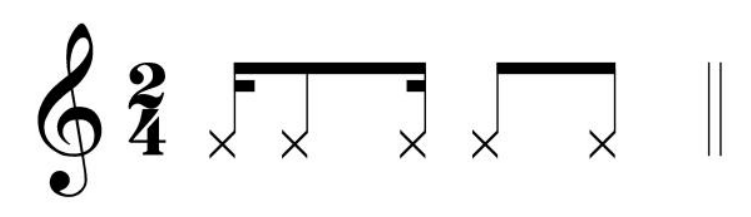

Ex. 2 - célula rítmica predominante no acompanhamento do lundu e do samba até o início da década de 1920.

Esse padrão, que traz a síncope no primeiro tempo do compasso 2/4, a que foi chamada por Mario de Andrade de "síncope característica", constituirá uma espécie de ponte ligando o lundu ao samba. Como é o caso, por exemplo, do samba carnavalesco de José Luiz de Morais, o Caninha (1883-1961), gravado pelo Bahiano em 1920, "Quem vem atrás feche a porta".

Só no final da década de 1920, com os sucessos de Sinhô (José Barbosa da Silva, 1888-1930) cantados por Mário Reis (1907-1981) e Francisco Alves (1898-1952) e as contribuições de Pixinguinha (Alfredo da Rocha Vianna Filho, 1897-1973), já em seu posto de arranjador pioneiro, é que o maxixe cantado vai ganhar em qualidade e originalidade, tanto nas introduções quanto nas melodias dos versos. Os arranjos de Pixinguinha para os sambas maxixados ou para peças de Ernesto Nazareth, escritos entre 1928 e 1935, vão impor um padrão de acompanhamento da terceira fase sobre 
material da primeira e da segunda, tornando esse momento, embora confuso, muito valioso para a compreensão do processo como um todo.

\section{Fase 3 - O maxixe levada}

Se a história do maxixe tivesse ido até a segunda fase e experimentado um declínio, não seria muito diferente da trajetória de tantos gêneros populares aqui e em outros países. A partir de uma fase de experiências, normalmente mais variada e interessante, se cristaliza uma fórmula e ela se esgota pela repetição. Mas com o maxixe música deu-se algo mais interessante e intrincado. A fase das experiências sincopantes com a polca foi eclipsada pelo sucesso da fórmula do maxixe funcional, mas todo um repertório de práticas desenvolvido pelas lideranças da chamada música dos chorões vai reaparecer resumido em uma levada, um jeito de tocar, um sotaque. E o surgimento dessa maneira de tocar estará fortemente associado à figura de Pixinguinha e a seu ambiente familiar. O próprio Pixinguinha, em seus depoimentos dados ao Museu da Imagem e do Som, deu uma boa ideia do quão musical era sua casa no bairro carioca do Catumbi.

Lá em casa tinha festa todos os dias. Era uma casa com oito quartos: quatro em cima e quatro em baixo. Muita gente morou lá. Sinhô, por exemplo, morou lá. Era conhecida como Pensão Vianna. (PIXINGUINHA, 1966, $1^{\circ}$ depoimento ao MIS).

Essas festas eram reuniões musicais que contavam com os chorões da época e foram um aprendizado inicial de música para o menino Pixinguinha, primeiro tocando cavaquinho e depois flauta. Dentre os músicos que moraram na chamada "Pensão Vianna", dois terão grande importância no desenvolvimento musical e na iniciação profissional de Pixinguinha: o trompetista e contrabaixista Bonfíglio de Oliveira (1891-1940) e Irineu de Almeida (1863-1914), que tocava trombone, bombardino e oficleide, esse último um instrumento hoje praticamente em desuso e que teve um relevante papel contrapontístico no choro da virada do século XIX para o XX. Irineu foi professor de Pixinguinha e logo percebeu o talento do menino, o levando para atuar em bailes, piqueniques e na orquestra do rancho 
carnavalesco Filhas da Jardineira. (SILVA; OLIVEIRA FILHO, 1998, p. 20; CABRAL, 1997, p. 23).

Ao longo da primeira década do século XX muitos grupos de choro gravaram e podemos ouvir claramente nessas gravações a célula rítmica característica da polca no acompanhamento, especialmente na palhetada do cavaquinho e nos ritmos tocados ao violão. Lembrando que, nos grupos que gravaram nesse período, a percussão não era usada, a responsabilidade pelo caráter rítmico era dividida pelo cavaquinho e o violão (CAZES, 2010, p. 40). A célula rítmica predominante era (Ex. 3):

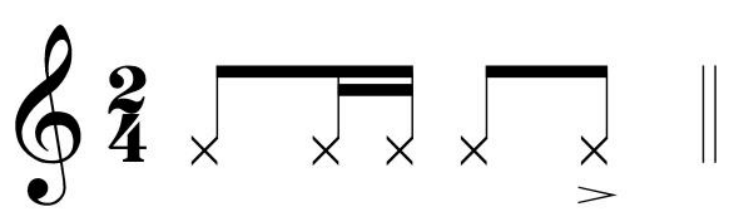

Ex. 3 - célula rítmica predominante no acompanhamento da polca.

Pois em 1910, com as gravações do grupo Choro Carioca, isso muda de forma sensível, com a chegada do maxixe levada, ora anunciado como polca, quando os andamentos são mais ligeiros, ora como tango, para as peças de andamento mais calmo.

O Choro Carioca era formado pelos irmãos Vianna: Pixinguinha com 13 anos de idade tocando flauta, China (Octávio Littleton da Rocha Vianna,1888-1927) e Leo Vianna (1889-?) nos violões e Henrique Vianna (1891-?) no cavaquinho. A liderança musical era exercida pelo professor de Pixinguinha, Irineu de Almeida que tocava o oficleide e assinava a maior parte das composições. Tudo no grupo era bem articulado, especialmente o ritmo da base com o contraponto do oficleide. Em alguns momentos das gravações podemos ouvir claramente o violão dobrando baixos com o oficleide, devido a pequenos batimentos de afinação. Participou do grupo também, em algumas gravações, o trompetista e ótimo compositor Bonfíglio de Oliveira, que se tornará um dos expoentes da terceira fase.

O que mudou de tão sensível no acompanhamento foi que saiu o acento da polca e entrou esse que até hoje é identificado como o do maxixe (Ex. 4): 


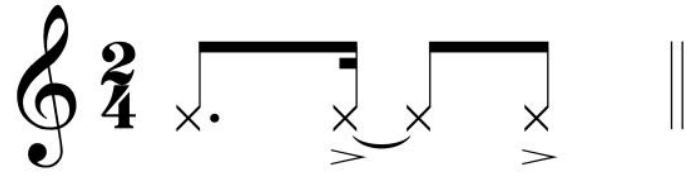

Ex. 4 - Célula rítmica predominante no maxixe levada.

A acentuação na $2^{\circ}$ e $4^{\circ}$ colcheias do compasso também será uma marca dessa fase, tanto nas melodias quanto nas linhas graves do contraponto.

Ao observar as gravações do repertório chorão de épocas pouco anteriores podemos verificar que, pelo menos no âmbito da banda de música, essa alteração já vinha sendo experimentada como pode ser verificado na gravação de "Cabeça de porco" de 1904, polca de Anacleto de Medeiros tocada pela Banda do Corpo de Bombeiros. No arranjo gravado, Anacleto muda a levada e acentua o maxixe na terceira parte com a caixa clara, para dar contraste e criar interesse.

Seria previsível que o novo padrão de acompanhamento, praticado pelo Choro Carioca passasse a prevalecer dali para frente, mas não foi o que ocorreu. Ao ouvirmos as gravações realizadas pelo Grupo do Pixinguinha em 1917 ou ainda pelos Oito Batutas na Argentina em 1923, não encontraremos o maxixe levada tocado de forma tão clara como no Choro Carioca. Essa constatação reforça a relevância desse grupo como uma espécie de vanguarda musical do ambiente do choro na década de 1910 e valoriza a figura de Irineu de Almeida, não só como o professor de música dos irmãos Vianna, mas também como compositor, instrumentista, organizador de conjuntos e arranjador, mesmo que os arranjos não fossem formalmente escritos.

É natural que a prática de um tipo de acompanhamento por um núcleo de músicos influencie no aparecimento de composições que o "aproveitem" bem e potencializem esse balanço. E realmente aparecem na obra de Pixinguinha músicas como "Oito batutas", "Os dois se gostam", "O rasga", que são perfeitas para o maxixe levada. Dentre as obras de Bonfíglio que se encaixam nessa categoria, dentre tantas, temos "Flamengo", "O bom filho à casa torna" e "Tudo dança”.

A partir da metade da década de 1930, os grupos de choro vão assumir o padrão do acompanhamento "sambado", consagrado pelo conjunto de Benedito Lacerda (CAZES, 2010, p. 84) e o maxixe levada vai ganhar sua aura de nostalgia. Isso aconteceu, por exemplo, nos programas O pessoal da Velha Guarda que Almirante 
(Henrique Foréis Domingues, 1908-1980) comandou na Rádio Tupy na segunda metade dos anos 1940 (CABRAL, 1990, p. 242), em que a orquestra comandada por Pixinguinha toca do jeito antigo (maxixe levada) enquanto o conjunto de Benedito executa do jeito novo, sambado.

A evocação do passado através do maxixe vai ter um momento de grande sucesso em 1954 com "Rio antigo" de Altamiro Carrilho (1924-2012), gravado pelo autor com sua bandinha (SEVERIANO, 1997, p. 309) e essa prática de dar um acento maxixado a tudo que se deseja associar ao passado, será muito usual ao longo da segunda metade do século XX. Posso citar aqui a trilha sonora da novela da TV Globo, O cravo e a rosa, que foi ao ar no ano 2.000 e que se passava em torno do ano de 1920. Tendo sido o arranjador desse trabalho, utilizei o maxixe levada como matéria prima essencial para toda a extensa trilha incidental.

Na segunda metade da década de 1990, o renascimento musical do bairro boêmio da Lapa, no Centro do Rio de Janeiro, fez com que grupos de choro voltassem a tocar para dançar, o que há tempos não se praticava. Pois o repertório que melhor funcionou para a dança foi justamente aquele que podia ser tocado com a levada do maxixe, e assim, músicas antes desconhecidas como o já citado "O bom filho à casa torna" de Bonfíglio de Oliveira se tornaram "novos" standards do choro. Não por acaso, um dos destaques dessa nova fase dançante do choro foi o trombonista Zé da Velha (José Alberto Rodrigues de Matos, 1942-), que se iniciou profissionalmente tocando com Pixinguinha e a Velha Guarda, ainda adolescente, praticando a fluência do maxixe levada.

\section{Considerações finais}

Cada fase do maxixe anteriormente proposta tem seus ecos até os dias atuais. Experiências de sincopação em busca de surpresa e movimento podem ser flagradas em tempo real numa roda de choro ou num estúdio onde se trabalha com samplers e ritmos eletrônicos. É comum, no repertório de cantores como Zeca Pagodinho (Jessé Gomes da Silva Filho, 1959-) ou Martinho da Vila (Martinho José Ferreira, 1938-), o uso da levada de maxixe em um refrão de um samba. Sucessos da 
música baiana nos anos 1990, como o emblemático "Segura o tchan”, também foram embalados na mesma levada. No Sul, o ritmo do vanerão, embora se aponte de forma recorrente à origem alemã dessa dança, tem um traço de maxixe. Enfim, embora seja associado quase sempre ao passado, o maxixe ainda é presente.

O trabalho aqui apresentado de forma bastante resumida propõe uma maneira de organizar as informações sobre o maxixe música, mesmo que em cada fase haja material bastante heterogêneo. Pensando-se cada fase com sua lógica interna, seus valores relativos, é possível entender melhor o que estava sendo almejado pelos compositores ou demandado pelo público. O que define cada fase não é um período de tempo, mas a intenção daqueles músicos que estavam fazendo o maxixe. Primeiro nas experiências de sincopação da polca. Depois, no preenchimento de oportunidades de trabalho no teatro de variedade e mais tarde, na busca de uma forma de acompanhamento que potencializasse a "característica gostosura" do maxixe. Uma gostosura que os chorões do século XXI continuam buscando e se deliciando com ela.

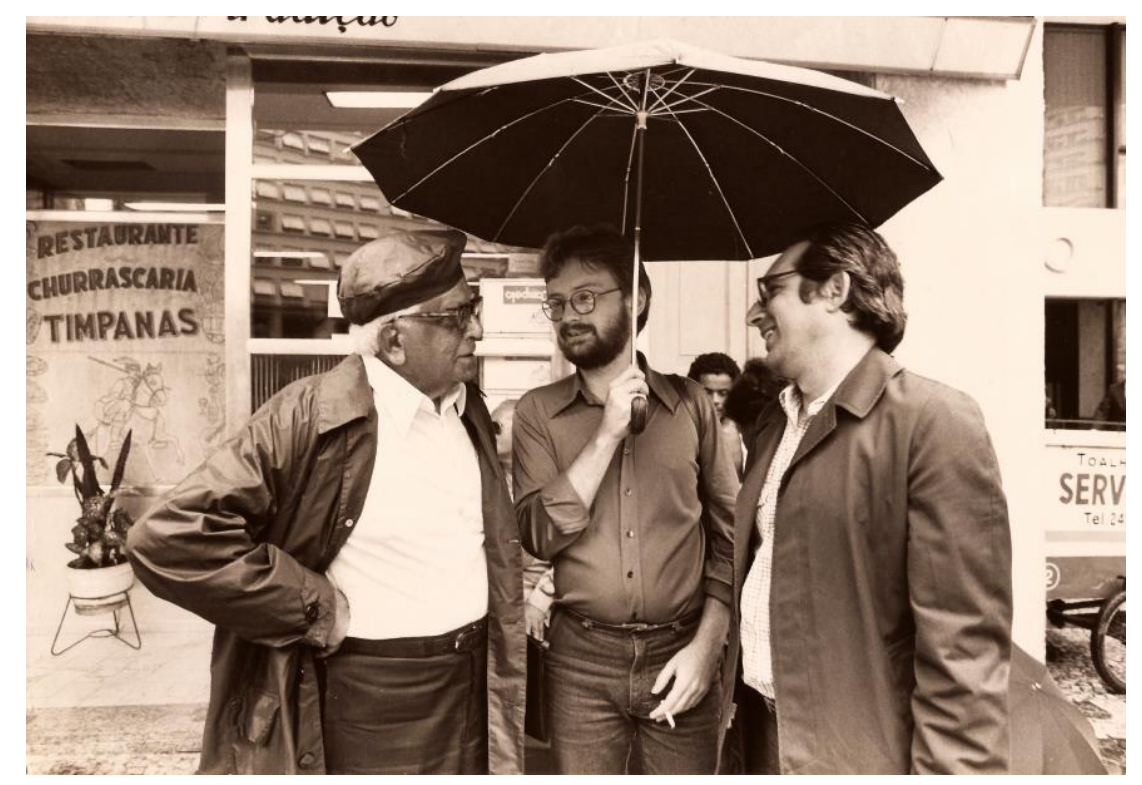

Ex.5 - Jota Efegê, o autor e o jornalista João Máximo, após um almoço para falar de maxixe em 1981 


\section{Referências bibliográficas}

ABREU, Martha Campos. O Império do Divino: festas religiosas e cultura popular no Rio de Janeiro, 1830-1900. Tese (Doutorado em História) - IFCH-UNICAMP, Campinas, SP, 1996.

ANDRADE, Mário de. Ensaio sobre a música brasileira. 3ed. Brasília: INL, 1972.

ANDRADE, Mário de. Música doce música. São Paulo: L. G. Miranda Editor, 1934.

AZEVEDO, Luiz Heitor. 150 Anos de Música no Brasil. Rio de Janeiro: Livraria José Olympio Editora, 1956.

CABRAL, Sérgio. No tempo de Almirante: uma história do rádio e da MPB. Rio de Janeiro: Francisco Alves, 1990.

CABRAL, Sérgio. Pixinguinha: vida e obra. Rio de Janeiro: Lumiar, 1997.

CAZES, Henrique. Choro: do quintal ao municipal. 4a Edição. Rio de Janeiro: Editora 34, 2010.

DINIZ, Edinha. Chiquinha Gonzaga: uma história de vida. Rio de Janeiro: Jorge Zahar, 2009.

EFEGE, Jota. Maxixe - a dança excomungada. Rio de Janeiro: FUNARTE, 1974.

GALLET, Luciano. 12 exercícios brasileiros. Rio de Janeiro: Ricordi, 1928.

GUERRA-PEIXE, César. Variações sobre o maxixe. O Tempo, São Paulo, 1954.

HORTA, Luiz Paulo. Dicionário de música. Rio de Janeiro: Jorge Zahar, 1985.

SANDRONI, Carlos. Feitiço Decente. Rio de Janeiro: Zahar, 2001.

SEVERIANO, Jairo; HOMEM DE MELLO, Zuza. A Canção no Tempo: 85 anos de músicas brasileiras (vol1:1901-1957). São Paulo: Editora 34, 1997.

SEVERIANO, Jairo. Uma história da música popular brasileira. São Paulo: Editora 34, 2008.

SILVA, Marília T. Barboza da; OLIVEIRA FILHO, Arthur L. Pixinguinha: Filho de Ogum Bexiguento. Rio de Janeiro: Gryphus, 1998.

VASCONCELOS, Ary. Panorama da música popular brasileira na Belle Époque. Rio de Janeiro: Sant'Anna, 1977 


\section{Acervos digitais consultados}

www.institutopianobrasileiro.com.br

www.ernestonazareth150anos.com.br

www.chiquinhagonzaga.com.br

www.marcellotupynamba.com

www.henriquealvesdemesquita.com.br

www.acervoims.com.br 